\title{
Species diversity and functional assessment of macroinvertebrate communities in Austrian rivers
}

Received: June 25, 2004 / Accepted: April 13, 2006 / Published online: June 23, 2006

\begin{abstract}
We applied an extensive data set from 211 locations along Austrian rivers to assess community structure and the ratios of functional feeding groups of benthic macroinvertebrates. A total of 569 taxa have been identified. At the catchment scale, the Enns, Salzach, and Traun Rivers exhibited the highest taxa richness whereas the Inn River showed the lowest richness. Beta-diversity was highest along the impounded and fragmented Enns and Drau Rivers. Consequently, high corridor diversity corresponded to a low degree of nestedness. Overall, scrapers and gathering-collectors dominated the benthic community. Further, the relationship between habitat conditions and metrics based on functional feeding groups were statistically analyzed to validate the potential of these metrics as indicators of ecosystem attributes. We examined four major ecosystem attributes: species diversity, material cycling, longitudinal material transport, and lateral material input. Multiple regression analyses for midorder rivers demonstrated that metrics were significantly related to habitat conditions. For example, the metric set indicating primary production was positively correlated with periphyton cover, dissolved oxygen, dominant sediment size, and average
\end{abstract}

C. Yoshimura ${ }^{1}(\square) \cdot K$. Tockner

Department of Limnology, Swiss Federal Institute of Aquatic Science and Technology (EAWAG), Switzerland

\section{Yoshimura}

Department of Civil and Environmental Engineering,

Interdisciplinary Graduate School of Medical and Engineering,

University of Yamanashi, Japan

T. Omura

Department of Civil Engineering, Graduate School of Engineering, Tohoku University, Japan

\section{O. Moog}

Institute of Hydrobiology and Water Management, University of Natural Resources and Applied Life Sciences (BOKU), Austria

\footnotetext{
${ }^{1}$ Present address:

Takeuchi-Ishidaira Laboratory, Interdisciplinary Graduate School of Medical and Engineering, University of Yamanashi, 4-3-11 Takeda,

Kofu, Yamanashi 400-8511, Japan

Tel. +81-55-220-8728; Fax +81-55-253-4915

e-mail: chihiroy@yamanashi.ac.jp
}

annual discharge. Overall, most metrics exhibited unique responses to habitat conditions, implying that they are useful proxies of ecosystem attributes. Thus, a functionbased approach based on macroinvertebrates has the potential to become an effective tool for the assessment of river ecosystems.

Key words Invertebrates - Biodiversity - Species diversity · Nestedness - Functional feeding groups - Ecosystem functions $\cdot$ Assessment

\section{Introduction}

Worldwide, streams and rivers are among the most threatened ecosystems (World Resources Institute 2001; Malmqvist and Rundle 2002). To assess the potential effects of multiple anthropogenic drivers on aquatic ecosystems, a function-based approach is required (Findlay et al. 2002). Such an approach uses structural and functional indicators as proxies of the ecological integrity and long-term sustainability of aquatic systems (Kerans and Karr 1994; Wright 2000). In general, ecological integrity is defined as the capacity of an ecosystem to support and maintain a balanced, integrated, and adaptive system having the full range of elements and processes expected in a region's natural habitat (Karr and Dudley 1981). Thus, functional assessment of the ecological integrity serves as a useful tool for assessing the state of ecosystems, although biological elements (e.g., rare and exotic species) have often been neglected.

Benthic macroinvertebrates are key components of aquatic food webs that link organic matter and nutrient resources (e.g., leaf litter, algae, and detritus) with higher trophic levels. By focusing on their multiple functional traits (e.g., feeding strategy, dispersal capacity), functional feeding groups (FFGs) have been applied to assess ecosystemlevel processes in rivers and wetlands (Merritt et al. 1999; Rawer-Jost et al. 2000; Gayraud et al. 2003). However, individual FFGs react differently to increasing human impacts, 


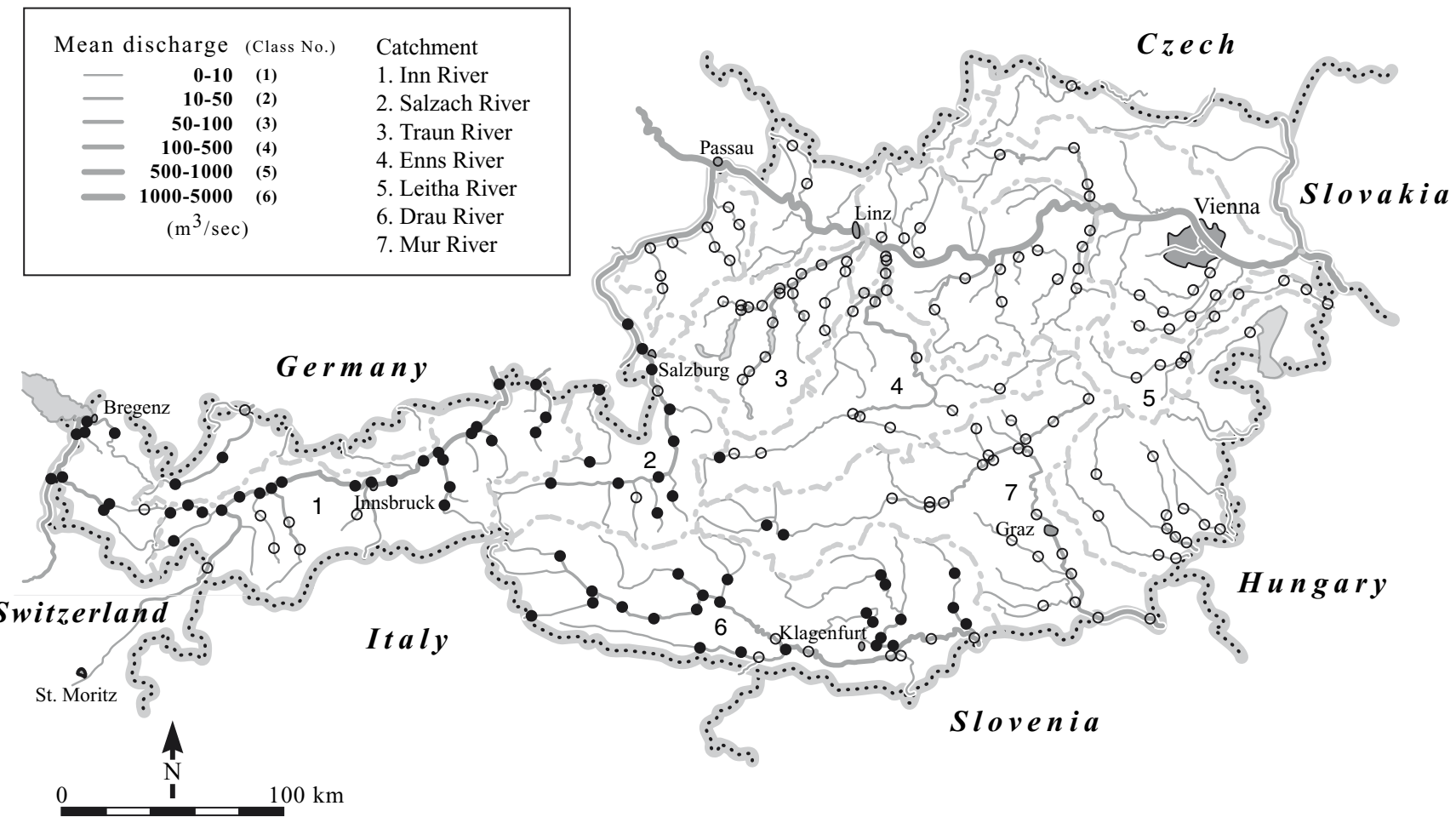

Fig. 1. Location of the 211 sampling sites along Austrian rivers (Bundesministerium für Land- und Forstwirtschaft, Umwelt und Wasserwirtschaft 1997). Closed circles, 78 sites used for the functional assessment; numbers 1-7, location of the seven major catchments

Table 1. Total number of river segments with a catchment area $>10 \mathrm{~km}^{2}$ in Austria (Wimmer et al. 2000) and the number of monitoring sites included in the present study

\begin{tabular}{llllllllllr}
\hline Stream order & 1 & 2 & 3 & 4 & 5 & 6 & 7 & 8 & 9 & Total \\
\hline Rivers & 72 & 416 & 964 & 531 & 146 & 33 & 5 & 3 & 1 & 2171 \\
$\quad \%$ & 3.3 & 19.2 & 44.4 & 24.5 & 6.7 & 1.5 & 0.2 & 0.1 & 0.1 & 100 \\
Monitoring sites & 0 & 0 & 4 & 31 & 80 & 70 & 26 & 0 & 0 & 211 \\
$\quad \%$ & 0 & 0 & 1.9 & 14.7 & 37.9 & 33.2 & 12.3 & 0 & 0 & 100 \\
\hline
\end{tabular}

which may limit their application (Resh 1994; Barbour et al. 2001). Yet, only a few studies have tested the effects of habitat alteration on these functional indicators (Minshall et al. 1982). Therefore, it is crucial to identify the habitat factors that affect different functional indicators and the ways in which they do so.

In the present article, we took advantage of an extensive data set on benthic invertebrates and habitat conditions available for all major Austrian rivers. First, we evaluated taxa diversity at different spatial scales. Second, we calculated the degree of nestedness for seven major catchments. Nestedness is a community property typical of fragmented and isolated ecosystems (Wright and Reeves 1992; Boecklen 1997). Third, we applied multivariate analyses to examine the sensitivity of functional indicators against major habitat factors. Based on benthic invertebrate composition, we calculated 13 metrics that better indicate ecosystem functions than simple FFG abundance data.

\section{Methods}

Study sites

Austria covers $84,000 \mathrm{~km}^{2}$ and has an average population density of 97 humans $\mathrm{km}^{-2}$. The total length of the entire river network is $\sim 100,000 \mathrm{~km}$ (Koller-Kreimel and Tomek 1999). The length of all rivers with a catchment area $>500 \mathrm{~km}^{2}$ is $5,200 \mathrm{~km}$ (in total, 52 rivers; Chovanec et al. 1996). The Danube River drains $96 \%$ of Austria.

From 1994 to 1997, aquatic invertebrates were sampled quantitatively at 211 monitoring sites (Fig. 1). Sites covered all 15 Austrian aquatic bioregions (Moog et al. 2001a) and included stream orders 4-7 (Wimmer and Moog 1994) (Table 1). Low-order streams and the Danube River (9thorder river) were not included in the present analysis for reasons of different sampling design and methodology. Based on degree of anthropogenic impacts, sites were 
classified as 0 (pristine), 1 (seminatural), 2 (hydrologically impaired), or 3 (both morphologically and hydrologically impaired) (Bundesministerium für Land- und Forstwirtschaft, Umwelt und Wasserwirtschaft 1998). Among the 211 sites, 78 sites were selected for detailed statistical analyses. The selected sites are located in midorder streams (stream order, 4-7) in western and southern Austria (see Fig. 1).

\section{Sampling design}

All sites were sampled during low flow in January and February to minimize seasonal variations and short-term impacts by floods (Hawkins and Sedell 1981). In addition, winter is the preferable season of larval growth for many species (Moog 1995; Wallace and Anderson 1996). Thus, the relationship between macroinvertebrates and habitat conditions is expected to be most significant during the low-flow period. Macroinvertebrates were sampled with a Surber (sampling area, $0.1 \mathrm{~m}^{2}$ ) or a Hess sampler (area, $0.043 \mathrm{~m}^{2}$ ). Mesh size was $100 \mu \mathrm{m}$. Two to three replicates were taken at each site. All individuals were counted and identified to lowest possible taxonomic level, mostly to species level. Total invertebrate biomass of each sample was measured as grams dry weight (gDW).

At each site, dominant grain size fraction, periphyton cover, water velocity, and water temperature were measured. Surface water was sampled at bimonthly intervals (monthly intervals in transboundary rivers). Samples were analyzed using standard methods as described by Aubrecht et al. (1993). Twenty-two of 50 physicochemical parameters were included in the present analyses.

\section{Assessment of species diversity}

Detailed analyses were carried out for the seven primary catchments (see Fig. 1). Local species diversity (alphadiversity) was calculated as the average number of taxa per site at the corridor and the catchment scale. A major component of biodiversity is beta-diversity, which provides an estimate of taxa turnover along a gradient (e.g., along a river corridor) (Ricklefs 1990). Beta-diversity is mostly neglected, although it can be an important indicator to assess the ecological integrity of rivers (Ward and Tockner 2001). We used the degree of dissimilarity as an index of beta-diversity (Soerenson index; Sorenson 1948). To estimate sampling efficiency and to develop a collector's curve for gamma-diversity (at the corridor and at the catchment scale) for the seven major rivers, macroinvertebrate data were "bootstrapped" following a jackknife procedure (after Heltshe and Forrester 1983). Before calculating diversity indices, we conducted taxonomic adjustment to avoid double counts of individual species. If individuals were identified to species level, individuals of that genus or at higher taxonomic levels were omitted.

The degree of nestedness was calculated using the "nestedness calculator" (Atmar and Patterson 1993). Its metric, "system temperature" (T), reflects the extent of order in a presence-absence species matrix. Perfectly nested communities have a $\mathrm{T}=0$ and maximally disordered ones a $\mathrm{T}=100$. Presence-absence matrices have been packed into a state of minimum unexpectedness. The characteristic " $T$ " of randomized matrices was calculated through Monte Carlo simulations (500 runs per test) and compared with observed "temperatures." Nestedness is an assemblage property typical of fragmented and isolated ecosystems (Wright and Reeves 1992; Boecklen 1997). Many communities exhibit a nested pattern when communities in areas with low diversity form subsets of richer sites (e.g., Kerr et al. 2000; Patterson and Atmar 1986).

\section{Assignment of functional feeding groups}

Most invertebrate species feed on various food sources, and they may change their feeding strategy depending on their life stage and on food availability (Wallace and Webster 1996). Thus, abundance and relative proportion (\%) of each functional feeding group (FFG) was calculated using a tenpoint system developed for Austrian and German rivers (Moog 1995; Bayerisches Landesamt für Wasserwirtschaft 1996). Ten points have been assigned for each taxon to indicate their feeding preferences (a list of taxa and FFG assignment is available at http://www.ccn.yamanashi.ac.jp/ $\sim$ chihiroy/FFG_assignment.xls). For example, Baetis alpinus has an equal feeding preference for attached algae and detritus. In this case, five points were assigned for scrapers and detritivores, respectively. For most taxa, except for Chironomidae (Diptera), feeding preferences were available at the genus level. The points for a shredder were equally divided to shredder-herbivores and shredderdetritivores if a separation was not provided in the relevant references.

Here, points were divided by ten and used to convert macroinvertebrate abundance from taxonomic classification to FFG as follows:

$$
\begin{aligned}
& \mathbf{A}=\left(\begin{array}{ccccc}
\alpha_{1,1} & \cdot & \cdot & \cdot & \alpha_{1,10} \\
\cdot & \cdot & & & \cdot \\
\cdot & & \alpha_{i, j} & & \cdot \\
\cdot & & & \cdot & \cdot \\
\alpha_{\mathrm{S}, 1} & \cdot & \cdot & \cdot & \alpha_{\mathrm{S}, 10}
\end{array}\right) \\
& \mathbf{N}=\left(n_{1}, n_{2}, n_{3}, \ldots n_{S}\right) \\
& \mathbf{X}=\mathbf{N} \cdot \mathbf{A} \\
& \mathbf{X}=\left(G_{1}, G_{2}, G_{3}, \ldots, G_{10}\right)
\end{aligned}
$$

where $\alpha_{i, j}$ is the point of taxon $i$ assigned for a functional feeding group $j(0 \leq \alpha \leq 1,0 \leq j \leq 10)$, and $\mathrm{S}$ is total number of observed taxa. Abundance in taxonomic classification and FFGs is shown as $\mathbf{N}$ and $\mathbf{X}$, respectively. Equation 3 shows the conversion of abundance from a taxonomic to FFG classification. 
Table 2. Functional feeding groups of macroinvertebrates related to ecosystem attributes

\begin{tabular}{|c|c|c|}
\hline \multicolumn{2}{|c|}{ Metrics based on taxa and functional feeding groups } & Ecosystem attributes \\
\hline \multicolumn{3}{|c|}{ Species diversity } \\
\hline F1 & Number of taxa & Taxa richness \\
\hline & Shannon-Weaver index & Diversity index (taxa composition) \\
\hline \multicolumn{3}{|c|}{ Material cycling } \\
\hline F3 & Abundance of shredder-herbivores and scrapers, G1 + G3 & Primary production \\
\hline $\mathrm{F} 4$ & $\begin{array}{l}\text { Ratio of shredder-herbivores and scrapers to shredder-detritivores, filterers, and } \\
\text { gathering-collectors, }(\mathrm{G} 1+\mathrm{G} 3) /(\mathrm{G} 2+\mathrm{G} 4+\mathrm{G} 5)\end{array}$ & Autotrophy/heterotrophy \\
\hline F5 & Total biomass (dry weight) & Secondary production \\
\hline F6 & Abundance of shredder-detritivores and gathering-collectors, G2 + G5 & Decomposition \\
\hline \multicolumn{3}{|c|}{ Longitudinal transport } \\
\hline F7 & Abundance of filterers, G4 & Longitudinal transport \\
\hline F8 & Ratio of filterers to shredder-detritivores and gathering-collectors, G4/(G2 + G5) & $\begin{array}{l}\text { Relative longitudinal transport (ratio of } \\
\text { suspended FPOM to benthic FPOM) }\end{array}$ \\
\hline \multicolumn{3}{|c|}{ Lateral input } \\
\hline F9 & Abundance of shredder-detritivores, G2 & Lateral input \\
\hline F10 & Ratio of shredder-detritivores to total abundance, G2/total abundance & $\begin{array}{l}\text { Relative lateral input (ratio of CPOM input from } \\
\text { riparian vegetation to total organic matter } \\
\text { input) }\end{array}$ \\
\hline \multicolumn{3}{|c|}{ Others } \\
\hline F11 & Ratio of shredder-detritivores to filterers and gathering-collectors, G2/(G4 + G5) & CPOM input/FPOM input \\
\hline F12 & Ratio of predators to total abundance, G6/total abundance & Top-down predator control \\
\hline F13 & $\begin{array}{l}\text { Ratio of scrapers and filterers to total shredders and gathering-collectors, } \\
\qquad(\mathrm{G} 3+\mathrm{G} 4) /(\mathrm{G} 1+\mathrm{G} 2+\mathrm{G} 5)\end{array}$ & Habitat stability \\
\hline
\end{tabular}

G1, shredder-herbivore; G2, shredder-detritivore; G3, scraper; G4, filterer; G5, gathering-collector; G6, predator; FPOM, fine particulate organic matter; CPOM, coarse particulate organic matter

Functional assessment

We used abundance data and ratios of FFGs as proxy indicators to assess four major river ecosystem attributes: (a) maintaining high species diversity, (b) cycling of carbon and nutrients, (c) longitudinal organic matter transport, and (d) lateral organic matter input. A total of 13 metrics were calculated based on the abundance and the ratio of FFGs (Table 2).

a. Species (taxa) diversity (F1, F2)

In the present study, we calculated two metrics: taxa richness (F1) and Shannon-Wiener index (Krebs 1999) (F2). Taxa diversity was reported at a level that is sufficient to quantify the relative composition of FFG taxa. The level was mostly genus (Moog 1995; Bayerisches Landesamt für Wasserwirtschaft 1996).

b. Material cycling (F3-F6)

Material cycling (spiralling and retention of carbon and nutrients) is one of the most important ecosystem functions in which macroinvertebrates are involved (Newbold et al. 1982; Meyer et al. 1988). We indirectly assessed the following attributes: (i) primary production, (ii) the ratio of production to respiration, (iii) secondary production, and (iv) decomposition (F3 to F6 in Table 2). The abundance of scrapers and shredder-herbivores (F3) is an estimate of primary production because they feed on periphyton and aquatic macrophytes (Hawkins et al. 1982; Richardson 1993; Wallace and Webster 1996). Evans-White and Lamberti (2005) suggested that scrapers may serve as "nutrient pumps" in stream ecosystems. The ratio of autotrophy to heterotrophy was analogized by the ratio of scrapers and shredder-herbivores to shredder-detritivores and total collectors (F4). It corresponds to the ratio of gross primary production to community respiration or, more generally, to the ratio of autotrophy to heterotrophy as used by Merritt et al. (1999). This ratio also reflects food and habitat conditions because turbidity, shading, or nutrient limitation may restrict autotrophy (Hawkins et al. 1982; Minshall et al. 1982). Secondary production was indicated by the total biomass of macroinvertebrates (F5). Finally, the total number of shredder-detritivores and gatheringcollectors (F6) indicates the potential amount of coarse particulate organic matter (CPOM) and the capacity of the system to decompose CPOM (Hieber and Gessner 2002).

c. Longitudinal transport (F7, F8)

Abundance of filterers (F7) and their ratio to shredderdetritivores and gathering-collectors (F8) were used to indirectly assess longitudinal material transport. Filterers are often supported by high organic seston concentration and stable habitat condition (Parker and Voshell 1983; Wotton 1987). Thus, their abundance is closely related to POM concentration transported downstream, although suspended POM transport may be retarded by their POM acquisition (Wallace et al. 1977). The metric F8 is comparative to the ratio of suspended fine particulate organic matter (FPOM) to benthic FPOM (Merritt et al. 1999). 
Table 3. Physicochemical variables used as independent variables in multiple regression analyses

\begin{tabular}{|c|c|c|c|c|c|}
\hline Variables & Unit & Mean & Range & & \\
\hline Stream order & _- & _- & 4 & - & 7 \\
\hline Mean annual discharge ${ }^{a}$ & - & - & 1 & - & 4 \\
\hline Main substrate ${ }^{\mathrm{b}}$ & _- & & 1 & _ & 6 \\
\hline Periphyton cover & $\%$ & 38 & 0 & _- & 90 \\
\hline Velocity & $\mathrm{cm} \mathrm{s}^{-1}$ & 63 & 0 & & 100 \\
\hline Anthropogenic impact on habitat ${ }^{\mathrm{c}}$ & - & - & 0 & - & 3 \\
\hline Specific conductivity & $\mu \mathrm{Scm}^{-1}$ & 247 & 57 & - & 471 \\
\hline Dissolved oxygen (DO) & $\mathrm{mgl}^{-1}$ & 11.3 & 8.4 & _- & 12.3 \\
\hline Dissolved organic carbon (DOC) & $\mathrm{mgl}^{-1}$ & 1.16 & 0.32 & - & 4.31 \\
\hline Total organic carbon (TOC) & $\mathrm{mgl}^{-1}$ & 1.44 & 0.32 & - & 6.92 \\
\hline Calcium & $\mathrm{mgl}^{-1}$ & 34.4 & 7.0 & - & 83.1 \\
\hline Sodium & $\mathrm{mgl}^{-1}$ & 3.3 & 0.8 & - & $\begin{array}{l}05.1 \\
14.9\end{array}$ \\
\hline Potassium & $\mathrm{mgl}^{-1}$ & 1.32 & 0.37 & - & 3.62 \\
\hline Nitrate-N & $\mathrm{mgl}^{-1}$ & 0.72 & 0.25 & _- & 3.98 \\
\hline Total inorganic nitrogen & $\mathrm{mgl}^{-1}$ & 0.79 & 0.27 & - & 4.24 \\
\hline Phosphate-P & $\mathrm{mgl}^{-1}$ & 0.019 & 0.001 & - & 0.218 \\
\hline Sulfuric acid & $\mathrm{mgl}^{-1}$ & 26.3 & 5.7 & - & 120.8 \\
\hline Chlorine & $\mathrm{mgl}^{-1}$ & 3.1 & 0.5 & - & 15.4 \\
\hline Organic halogen compounds- $\mathrm{Cl}$ & $\mu g l^{-1}$ & $\begin{array}{l}5.1 \\
4.3\end{array}$ & $\begin{array}{l}0.5 \\
1.0\end{array}$ & $\begin{array}{l}- \\
-\end{array}$ & $\begin{array}{l}15.4 \\
12.2\end{array}$ \\
\hline
\end{tabular}

d. Lateral input (F9, F10)

Allochthonous CPOM derived from terrestrial systems is an essential food source for shredders, playing a key role in the conversion of CPOM into FPOM (Cummins et al. 1989; Graça et al. 2001). Rivers receive a large proportion of their energy input as CPOM from terrestrial litter, which is the primary food source for shredderdetritivores (Cummins and Klug 1979; Dobson and Hildrew 1992). We calculated two metrics, namely, the number of shredder-detritivores (F9) and the ratio of shredder-detritivores to total abundance, as indicators of lateral organic matter input (F10).

e. Other ecosystem attributes (F11-F13)

Three additional ecosystem attributes were assessed: (i) the ratio of CPOM to FPOM, (ii) top-down predator control and (iii) habitat stability. They were indirectly calculated as (i) the ratio of shredder-detritivores to gathering-collectors and filterers (F11), (ii) the ratio of predators to total abundance (F12), and (iii) the ratio of scrapers and filterers to total shredders and gatheringcollectors (F13) (Merritt et al. 1999).

\section{Statistical analyses}

Based on abundance and ratio of FFGs, 13 metrics (F1F13) were calculated for all 211 sites to indicate ecosystem attributes. Among these sites, 78 sites for which detailed habitat information was available were selected for detailed analyses of the relationship between physicochemical variables and ecosystem functions (F1-F13). To exclude seasonality from statistical analyses, all 78 sites were sampled in winter (January-February). In addition, 19 physicochemical variables were selected as independent variables to avoid redundancy by partial correlation analyses: those variables included carbon, nutrient, heavy metal, and chlorine concentrations (average annual values; Table 3).

The relationship between habitat conditions and individual metrics was calculated by multiple regression analyses (forward selection with $F>1.0$; Statistica; Kernel release 6.0, StatSoft, Tulsa, USA). All metrics (F1-F13) were transformed (log or arcsine) to meet assumptions of normality and homogeneity. Before multiple regression analyses, relationships between these metrics and stream order were tested using analysis of variance (ANOVA). If stream order significantly affected individual metrics, it was expressed as a dummy variable and then included in multiple regression analyses. In addition, correlations between the metrics (F1F13) were tested with sequential Bonferroni procedures (Rice 1989).

\section{Results}

Species diversity and nestedness

At 211 sampling sites, a total of 569 taxa of benthic invertebrates were identified, mostly to species level. The average density of benthic macroinvertebrates was 50,367 individuals $\mathrm{m}^{-2}$ (range, 4,750-870,000). Chironomidae (221 taxa), Trichoptera (65), Oligochaeta (64), and Ephemeroptera (62) were the most diverse groups. The average number of taxa per site was $39( \pm 14)$, ranging from 4 to 73 . Overall, 210 taxa were found in less than $1 \%$ of the sites (1-2 sites), 461 taxa in $<10 \%$ of all sites. Numerically dominant taxa $(>1 \%$ of all individuals) included mainly oligochaetes and chironomides (Table 4). Together, the 10 most abundant 
Table 4. Dominant taxa with a relative abundance $>1.0 \%$ each (pooled data)

\begin{tabular}{lcc}
\hline Taxon & Relative abundance (\%) & Relative frequency $(\%)^{a}$ \\
\hline Vejdovskyella spp. & 10.1 & 2.4 \\
Propappus volki & 9.8 & 54.5 \\
Nais elinguis & 8.4 & 49.3 \\
Micropsectra atrofasciata & 6.3 & 24.2 \\
Limnodrilus hoffmeisteri & 3.7 & 27.5 \\
Stylodrilus heringianus & 3.1 & 67.8 \\
Synorthocladius semivirens & 2.6 & 50.7 \\
Nais alpina & 2.5 & 54.0 \\
Tvetenia calvescens & 1.8 & 66.8 \\
Orthocladius rivicola & 1.7 & 43.6 \\
Psychomyia pusilla & 1.7 & 53.6 \\
Gammarus fossarum & 1.7 & 40.3 \\
Nais bretscheri & 1.6 & 41.2 \\
Parametriocnemus stylatus & 1.5 & 70.1 \\
Paratrichocladius rufiventris & 1.4 & 73.0 \\
Orthocladius frigidus & 1.3 & 43.1 \\
Nais simplex & 1.3 & 5.2 \\
Cheumatopsyche lepida & 1.3 & 9.5 \\
Tubifex tubifex & 1.1 & 14.2 \\
Nais communis & 1.0 & 49.3 \\
Eukiefferiella devonica & 1.0 & 54.0 \\
Ancylus fluviatilis & 1.0 & 45.0 \\
Total & 65.8 & - \\
\hline Relative frequency, proportis & &
\end{tabular}

${ }^{\text {a }}$ Relative frequency, proportion (\%) of sites occupied by each individual taxon

taxa accounted for $50 \%$ of all individuals. Generally, those abundant taxa were also the most frequent ones. However, Vejdovskyella spp. and Nais simplex were found in very high densities at a few locations (mainly along the impounded Drau River).

High corridor diversity (gamma-diversity) was observed along the Enns, Traun, Leitha, and Mur Rivers, where $>140$ taxa were estimated for a total of six sampling sites (jackknifed diversity; Table 5). At the catchment scale, the Enns, Traun, Drau, and Salzach Rivers exhibited highest taxa richness ( $>200$ taxa for 10 sampling sites), whereas the Inn River had only 114 taxa (10 sites). Diversity calculated by jackknife procedures was similar to observed values.

At the corridor scale, beta-diversity (dissimilarity between pairs of sites) ranged from 0.45 to 0.81 . Corridors with higher local (alpha-)diversity exhibited lower betadiversity. The highest beta-diversity (lowest similarity between pairs of sites) was found along the Enns River (0.81), followed by the Drau River (0.70). Beta-diversity between sites increased with spatial distance, indicating a gradual faunal change along corridors (Fig. 2). Dissimilarity between the most upstream and the most downstream site was always $>0.5$. Average dissimilarity was lowest along the main corridor of the Salzach River.

In general, high corridor diversity corresponded to a low degree of nestedness, except for the Enns River. In the Traun and Leitha Rivers system, temperature (T), an index of the degree of nestedness, was not significantly different from $\mathrm{T}$ calculated from a random community. This result means that each site within those catchments had a distinct macroinvertebrate community. In contrast, invertebrates in the Inn, Salzach, Enns, Drau, and Mur catchments were significantly nested.

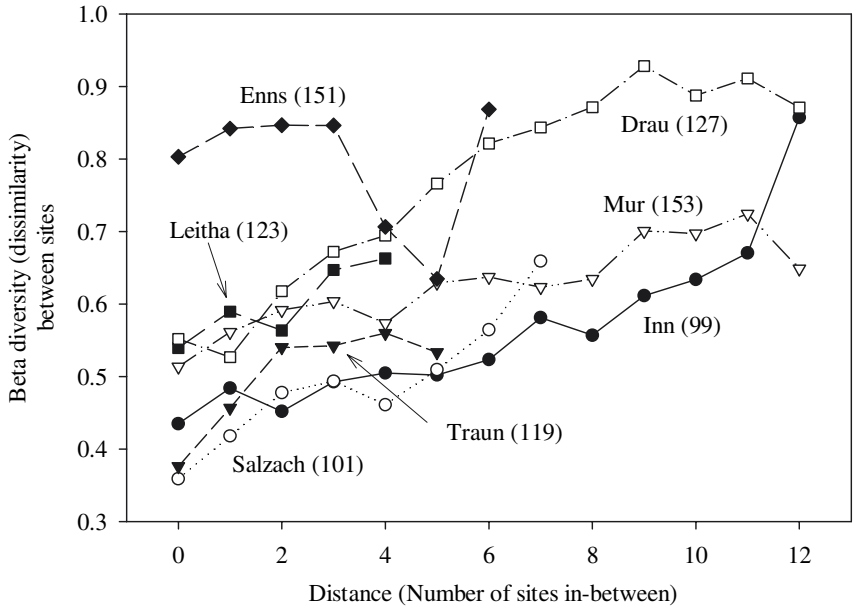

Fig. 2. Average beta-diversity (dissimilarity) between all pairs of sites along selected Austrian rivers (average Soerenson index for each pair of sites). Distance between study sites ranged from 10 to $40 \mathrm{~km}$. Numbers in parentheses, gamma-diversity of the main corridor

Functional feeding groups

All macroinvertebrates (569 taxa from 211 sites; average density, $50,367 \mathrm{~m}^{-2}$ ) were classified according to their functional feeding preference (Fig. 3). However, for $32.8 \%$ of the individuals it was not possible to accurately assess their feeding preferences because information was not available or taxonomic resolution was too coarse. Gathering-collectors and scrapers dominated benthic communities $(>50 \%$ of all individuals), which suggests that detritus and epilithic algae (periphyton) were the primary energy sources for macroinvertebrate communities. If unidentified individuals 
Table 5. Summary statistics for major corridors and catchments

\begin{tabular}{|c|c|c|c|c|c|c|c|}
\hline & Inn & Salzach & Traun & Enns & Leitha & Drau & Mur \\
\hline \multicolumn{8}{|l|}{ Main corridor } \\
\hline Sites along corridor & 14 & 9 & 7 & 8 & 6 & 14 & 14 \\
\hline Local diversity $^{\mathrm{a}}$ & $32 \pm 10$ & $38 \pm 12$ & $48 \pm 4$ & $36 \pm 19$ & $45 \pm 8$ & $32 \pm 15$ & $38 \pm 10$ \\
\hline $\begin{array}{l}\text { Corridor diversity } \\
\quad(\text { calculated, } 6 \text { sites })\end{array}$ & $100 \pm 6$ & $116 \pm 10$ & $149 \pm 9$ & $192 \pm 16$ & $171 \pm 7$ & $130 \pm 9$ & $147 \pm 11$ \\
\hline Beta diversity & 0.51 & 0.45 & 0.48 & 0.81 & 0.58 & 0.70 & 0.60 \\
\hline Nestedness (T) & 38.2 & 35.3 & 64.2 (n.s.) & 40.2 & 60.7 (n.s.) & 33.0 & 40.6 \\
\hline \multicolumn{8}{|l|}{ Catchment } \\
\hline Sites in the catchment & 30 & 22 & 19 & 14 & nd & 33 & 25 \\
\hline $\begin{array}{l}\text { Catchment diversity } \\
\text { (observed) }\end{array}$ & 117 & 206 & 190 & 198 & nd & 185 & 176 \\
\hline $\begin{array}{l}\text { Catchment diversity } \\
\quad \text { (calculated, } 10 \text { sites) }\end{array}$ & $114 \pm 5$ & $213 \pm 14$ & $205 \pm 11$ & $244 \pm 12$ & nd & $239 \pm 13$ & $171 \pm 12$ \\
\hline
\end{tabular}

Taxa diversity was predicted at the corridor and catchment scale following jackknife procedures (after Heltshe and Forrester 1983)

Local diversity, average $( \pm \mathrm{SD})$ number of taxa per sampling site; beta-diversity, average degree of dissimilarity (Soerenson index); nestedness, system temperature (T) calculated after Atmar and Patterson (1993); n.s., calculated temperatures were not significantly different from randomly calculated temperatures (Monte-Carlo simulation, 500 runs); nd, not determined

Leitha catchment: all study sites were located along the main corridor

${ }^{a}$ Mean \pm SD

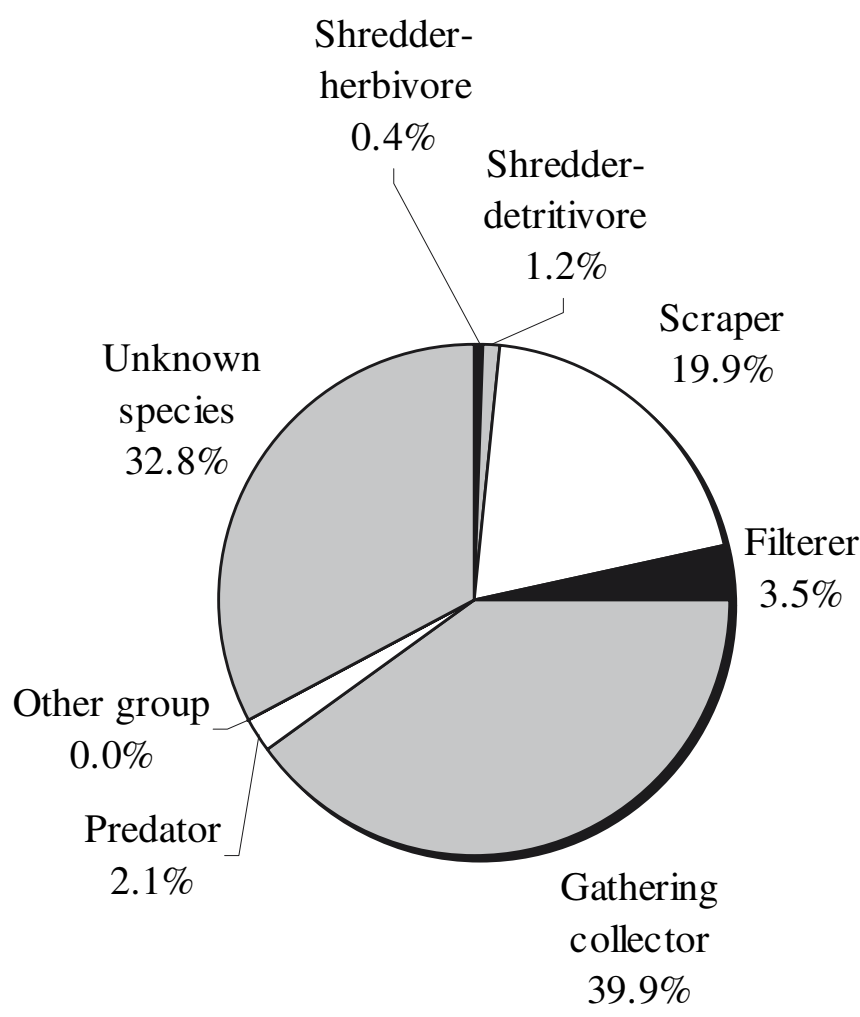

Fig. 3. Relative proportion (\%) of individuals belonging to individual functional feeding groups (pooled data from 211 sites). Average number of individuals per site was $50,367 \mathrm{~m}^{-2}$

were excluded, the proportions (based on abundance) of gathering-collectors and scrapers were $59.5 \%$ and $29.7 \%$, respectively. Gathering-collectors were mainly composed of Chironomidae and Trichoptera taxa. Scrapers included many Trichoptera and Ephemeroptera taxa. In contrast, relative proportion of filterers and shredders was 3.5\% and $1.6 \%$ (of individuals), respectively.
Ecosystem attributes

Among the 78 sites selected for detailed functional assessments, 8 sites were classified as pristine or seminatural. For all sites, the $\mathrm{pH}$ value ranged from 7.28 to 8.50 (mean, 7.94). Average concentration of dissolved organic carbon (DOC), nitrate- $\mathrm{N}$, and soluble reactive phosphorus was $1.16,0.72$, and $0.019 \mathrm{mgl}^{-1}$, respectively (see Table 3 ). The saprobic value, an index of organic pollution (Zelinka and Marvan 1961), ranged from 1.44 to 3.31. Several monitoring sites were located in limestone areas. There, calcium and magnesium concentrations as well as specific conductance decreased from upstream to downstream sections.

Stream order significantly affected the biomass (F5) (ANOVA; $F=4.3, P<0.01, d f=3$ ) and the abundance of filterers (F7) $(F=2.9, P=0.041, d f=3)$. For all other attributes, no significant differences among stream orders were found. All functional metrics (F1-F13) were well explained by physicochemical variables, with multiple correlation coefficients ranging from 0.44 to $0.73(P<0.014$; Table 6). Among the metrics, abundance of filterers, as an indicator for longitudinal material transport (F7), exhibited the highest correlation coefficients. It had a significant positive correlation with stream order, periphyton cover, dissolved oxygen (DO), and chlorine concentration. The diversity index (F2) was significantly related to discharge, DO, total organic carbon (TOC), calcium, total inorganic nitrogen, and phosphate-P concentration. Especially discharge, TOC, and inorganic nutrients exhibited high partial correlation coefficients.

Among all independent variables, DO was the single most important variable that explained most macroinvertebrate-based metrics. Dissolved oxygen exhibited a significant correlation with six metrics (F2-F4, F7, F8, and F13). Correlation coefficients were positive except for F4 (ratio of herbivores to detritivores as an indicator of $\mathrm{P}: \mathrm{R}$ ratio). Periphyton, DOC, TOC, sodium and potassium were 
Table 6. Results from multiple regression analyses showing relationships between metrics based on functional feeding groups (F1-F13, see Table 2) and physicochemical parameters

\begin{tabular}{|c|c|c|c|c|c|c|c|c|c|c|c|c|c|}
\hline \multirow[t]{2}{*}{ Statistics/Parameter } & \multicolumn{13}{|c|}{ Metrics based on taxa and functional feeding groups (see Table 2) } \\
\hline & $\mathrm{F} 1$ & $\mathrm{~F} 2$ & F3 & $\mathrm{F} 4$ & F5 & F6 & F7 & F8 & F9 & F10 & F11 & F12 & F13 \\
\hline Mean & 55 & 3.59 & 8812 & 0.95 & 16 & 10860 & 578 & 0.06 & 638 & 0.02 & 0.10 & 0.02 & 1.02 \\
\hline Maximum & 100 & 4.96 & 78782 & 4.10 & 104 & 70310 & 8947 & 0.37 & 9848 & 0.12 & 0.77 & 0.15 & 3.88 \\
\hline Minimum & 14 & 1.80 & 99 & 0.03 & 0 & 486 & 1 & 0.00 & 3 & 0.00 & 0.00 & 0.00 & 0.03 \\
\hline$R$ (Multiple correlation coefficient) & 0.51 & 0.57 & 0.56 & 0.49 & 0.70 & 0.51 & 0.73 & 0.66 & 0.44 & 0.64 & 0.61 & 0.46 & 0.57 \\
\hline$F$ & 3.58 & 4.19 & 4.68 & 3.80 & 9.72 & 3.54 & 10.1 & 5.95 & 4.44 & 8.39 & 6.86 & 2.75 & 3.54 \\
\hline$p$ & $0.002^{* *}$ & $<0.001 * *$ & $<0.001 * *$ & $0.002 * *$ & $<0.001 * *$ & $0.002^{* *}$ & $<0.001^{* *}$ & $<0.001 * *$ & $0.003 * *$ & $<0.001 * *$ & $<0.001 * *$ & 0.014 & $0.001 * *$ \\
\hline Standard error of estimate & 1.55 & 3.91 & 0.92 & 0.17 & 0.68 & 16.2 & 1.21 & 0.09 & 1.27 & 0.09 & 0.14 & 0.08 & 0.21 \\
\hline Stream order $\alpha$ & NA & NA & NA & NA & $0.53 * *$ & NA & $0.28 * *$ & NA & NA & NA & NA & NA & NA \\
\hline Stream order $\beta$ & NA & NA & NA & NA & NA & NA & 0.12 & NA & NA & NA & NA & NA & NA \\
\hline Mean annual discharge & - & $-0.28 * *$ & 0.16 & - & -0.14 & - & - & 0.10 & -0.13 & $-0.31 * *$ & -0.19 & -0.19 & - \\
\hline Main substrate & -0.21 & - & -0.14 & 0.13 & - & - & - & - & - & 0.13 & - & 0.23 & -0.17 \\
\hline Periphyton cover & 0.12 & _- & $0.32 * *$ & - & $0.24 * *$ & $0.25 *$ & $0.22 *$ & - & 0.14 & -0.17 & - & -0.17 & - \\
\hline Velocity & - & - & - & - & - & - & - & -0.12 & - & - & - & - & - \\
\hline Anthropogenic impact on habitat & 0.17 & 0.18 & - & -0.12 & - & - & - & 0.10 & -0.14 & - & - & - & 0.11 \\
\hline Specific conductivity & - & - & - & - & - & $-0.81 *$ & - & $0.45^{* *}$ & - & - & - & - & 0.28 \\
\hline Dissolved oxygen (DO) & 0.15 & $0.24 *$ & $0.35^{* *}$ & $-0.30^{*}$ & - & - & $0.36^{* *}$ & $0.42 * *$ & _- & - & - & 0.16 & $0.43 * *$ \\
\hline Dissolved organic carbon (DOC) & $0.46^{* *}$ & - & - & - & - & - & - & - & - & $-1.08 *$ & $-1.04 *$ & - & -0.69 \\
\hline Total organic carbon (TOC) & - & $-0.65^{* *}$ & - & - & 0.28 & - & - & - & - & $0.93 *$ & $1.17 * *$ & - & 0.49 \\
\hline Calcium & 0.14 & $0.27 *$ & - & - & - & 0.55 & - & - & - & - & 0.20 & - & - \\
\hline Sodium & - & -0.18 & - & - & - & - & - & $0.27 *$ & $-0.40 * *$ & $-0.37 * *$ & -0.24 & 0.17 & - \\
\hline Potassium & - & - & - & $-0.30 *$ & -0.20 & $-0.34 *$ & - & $0.32 *$ & - & - & - & - & $0.50 * *$ \\
\hline Nitrate-N & _- & - & - & - & - & - & 0.31 & - & _- & - & - & - & - \\
\hline Total inorganic nitrogen & - & $1.11 * *$ & - & - & - & - & - & - & - & - & - & 0.23 & - \\
\hline Phosphate-P & -0.13 & $-0.50^{* *}$ & 0.14 & 0.21 & - & $0.35^{*}$ & -0.14 & -0.14 & - & - & - & - & -0.20 \\
\hline Sulfuric acid & - & - & - & $-0.23^{*}$ & - & - & - & -0.18 & - & - & - & -0.16 & 0.07 \\
\hline Chlorine & - & - & 0.14 & - & 0.24 & 0.32 & $0.42 *$ & - & - & - & -0.43 & - & - \\
\hline Organic halogen compounds-CI & - & - & 0.18 & - & $0.24 *$ & 0.25 & 0.15 & - & - & - & - & - & - \\
\hline
\end{tabular}

Stream orders $\alpha$ and $\beta$ were dummy variables expressing differences between 4th-6th and 7th, and 4th and 5th-7th order, respectively

$n=78$

NA, not analyzed

Standardized partial correlation coefficients $(* *, P<0.01 ; *, 0.01<P<0.05)$ are shown for each parameter 
Table 7. Correlation matrix of 12 metrics corrected with sequential Bonferroni procedures

\begin{tabular}{|c|c|c|c|c|c|c|c|c|c|c|c|}
\hline & F1 & $\mathrm{F} 2$ & F3 & F4 & F5 & F6 & F7 & F8 & F9 & F11 & F12 \\
\hline $\begin{array}{l}\text { F1 } \\
\text { F2 }\end{array}$ & 0.31 & & & & & & & & & & \\
\hline $\begin{array}{l}\text { F3 } \\
\text { F4 } \\
\text { F5 } \\
\text { F6 }\end{array}$ & $\begin{array}{l}0.57 * * \\
-0.31 \\
0.57 * * \\
0.30\end{array}$ & $\begin{array}{r}-0.06 \\
-0.17 \\
0.09 \\
-0.28\end{array}$ & $\begin{array}{r}-0.54 * * \\
0.51 * * \\
0.65 * *\end{array}$ & $\begin{array}{l}0.00 \\
0.27\end{array}$ & $0.53 * *$ & & & & & & \\
\hline $\begin{array}{l}\text { F7 } \\
\text { F8 }\end{array}$ & $\begin{array}{l}0.45^{* * *} \\
0.28\end{array}$ & $\begin{array}{l}0.24 \\
0.42 * *\end{array}$ & $\begin{array}{l}0.37 * * \\
-0.02\end{array}$ & $\begin{array}{r}0.01 \\
-0.13\end{array}$ & $\begin{array}{l}0.65^{* *} \\
0.36^{*}\end{array}$ & $\begin{array}{c}0.37^{*} \\
-0.22\end{array}$ & $0.82 * *$ & & & & \\
\hline F9 & 0.24 & -0.02 & $0.42 * *$ & -0.19 & 0.16 & 0.29 & -0.01 & -0.20 & & & \\
\hline $\begin{array}{l}\text { F11 } \\
\text { F12 } \\
\text { F13 }\end{array}$ & $\begin{array}{r}-0.01 \\
-0.14 \\
0.34\end{array}$ & $\begin{array}{l}0.17 \\
0.30 \\
0.21\end{array}$ & $\begin{array}{l}-0.09 \\
-0.49 * * \\
0.54 * *\end{array}$ & $\begin{array}{c}-0.30 \\
0.33 \\
-0.97 * *\end{array}$ & $\begin{array}{r}-0.21 \\
-0.03 \\
0.05\end{array}$ & $\begin{array}{l}-0.39 * * \\
-0.32 \\
-0.26\end{array}$ & $\begin{array}{r}-0.25 \\
0.16 \\
0.13\end{array}$ & $\begin{array}{c}-0.04 \\
0.38^{*} \\
0.28\end{array}$ & $\begin{array}{c}0.72 \text { ** } \\
-0.24 \\
0.12\end{array}$ & $\begin{array}{l}0.04 \\
0.22\end{array}$ & -0.26 \\
\hline
\end{tabular}

$n=78$

See Table 2 for the metrics (F1-F13); F10 (ratio of shredder-detritivores) was excluded from the analysis because it obviously was correlated to F9 (abundance of shredder-detritivores)

Significant correlation coefficients at $P=0.01$ and $P=0.05$ are marked with * and $* *$, respectively

significantly related to several metrics (Table 6). Periphyton biomass, for example, was positively correlated with metrics indicating material cycling (F3, F5, and F6) and longitudinal material transport (F7). DOC exhibited a positive correlation with taxa richness (F1) and a negative correlation with the ratio of shredders to detritivores (F10). TOC was negatively correlated with diversity index (F2) and positively with ratio of shredders to detritivores (F10). Dominant substrate class, flow velocity, anthropogenic impact, and nitrate concentration, however, were not significantly related to any of the calculated metrics.

Correlation analyses among metrics revealed that $\mathrm{F} 1$ and F2 (species diversity) were positively correlated with F7 and F8, which are both based on abundance of filterers (Table 7). Taxa richness showed significant correlations (correlation coefficients $>0.45$ ) with F3 (abundance of herbivores) and F5 (total biomass). Metrics for material cycling (F3, F5, and F6) were correlated with metrics indicating longitudinal transport and lateral input (F7 and F9). Overall, F3 (abundance of herbivores) was correlated with most other metrics (F1, F4-F7, F9, F12, and F13). In addition, there was a negative correlation between F3 and F4 (the ratio of herbivores to detritivores).

\section{Discussion}

Species diversity

We identified 569 taxa, corresponding to $21 \%$ of the entire aquatic macroinvertebrate fauna listed for Austria, which includes all species living in running waters, lakes, wetlands, springs, and groundwaters (Moog 1995; Moog et al. 2001b). This proportion is considered as high because only mediumsize rivers were considered and individual sites were only sampled once. Tributaries, especially along the Salzach and Drau Rivers, considerably increased total species richness at the catchment scale (see Table 5). In general, tributaries exhibit fewer human alterations than the main corridor (Federal Environment Agency of Austria 2002). Multiple correlations indicated, as expected, that diversity $(\mathrm{F} 1, \mathrm{~F} 2)$ increased with natural habitat conditions (which occurred primarily in headwater sections). Our results suggest that some taxa are dominant in relatively large river sections as discharge was only significantly related to the diversity index (F2) but not to taxa richness (F1). Additional detailed hydrogeomorphic conditions might help to better explain the expected longitudinal trend (Lorenz et al. 2004).

In their natural state, river corridors are longitudinally connected systems, whereas ponds form more-isolated habitats. In lotic ecosystems, migration and dispersal are essential phenomena. Thus, habitat fragmentation as well as water abstraction can cause discontinuities along corridors, which may reduce the dispersal of aquatic organisms. Therefore, community structure at the catchment scale may reflect anthropogenic impacts and biogeographic differences. In the present study, the Enns River exhibited very high corridor and catchment diversity as well as a high turnover (high beta-diversity) between adjacent sites. This result indicates that each individual site harbours a rich and relatively unique macroinvertebrate community (see Table 5, Fig. 2). A high proportion of protected areas in the catchment might account for this high species diversity in the Enns River catchment, although only short sections along the main stem maintained good hydromorphological quality (Muhar et al. 2000). In contrast, the Inn and Drau Rivers, which are fragmented by impoundments, exhibited a low alpha-diversity but a high degree of nestedness. There, species-poor sites contained faunal subsets of the richest sites. In this case, the conservation of the most diverse sites, mainly headwaters, deserves highest priority.

Both biogeographic and anthropogenic factors are supposed to be responsible for differences in taxa diversity at the catchment scale (Bauernfeind and Moog 2000; Wimmer et al. 2000; Ofenböck et al. 2002). Most study sites within the Inn catchment were located in the aquatic bioregions 
"Glaciated Crystalline Alps" and "Limestone Alps." Turbid glacial meltwater probably confines taxa diversity at the local level. In contrast, the Traun and Enns catchments, which include sites from different longitudinal regions (rhithral to hyporhithral), showed relatively high diversity. These catchments drain several biogeographic regions including the limestone area.

\section{Functional metrics and ecosystem attributes}

Multiple correlation analyses revealed significant relationships between habitat conditions and macroinvertebrate metrics, implying that these metrics can be used for the functional assessment of rivers. Functional feeding groups (FFGs) emphasise the multiple linkages that exist between food resources and the capability of invertebrates to successfully acquire these resources (Merritt et al. 1999; Wallace and Webster 1996; Barbour et al. 2001). Thus, a function-based assessment is more directly related to ecosystem processes than to solely taxonomic composition.

For example, species diversity (F1 and F2) was correlated with high DO, low TOC, and low phosphate concentration. Metrics used to indicate material cycling (F3-F6) were significantly related to DO and periphyton cover. Interestingly, higher phosphate concentration seemed to support microbial growth, which provides a better POM quality for detritivores (F6), as also reported by Lawson et al. (1984). Further, abundance of filterers (F7) increased downstream, which means that suspended organic matter also increased, as predicted by the River Continuum Concept (Vannote et al. 1980). We found some limitations to evaluate these metrics based on our database because parameters explaining hydrogeomorphic conditions were not equally documented from the sampling sites. Thus, further studies are required to investigate the meaning and validity of metrics, especially in respect to flow regime, local flow conditions, and habitat stability.

Inorganic nutrients stimulate periphyton and microbial growth. This biofilm is an important food source for scrapers and shredder-detritivores (Battin et al. 2003; Rezanka and Hershey 2003). Positive correlations between inorganic phosphorus and metrics indicating material cycling (primary and secondary production and decomposition by shredders) were found in the present study. However, inorganic phosphorus was negatively related to species diversity (F2), which suggests that an excess in phosphorus can lead to an unbalanced macroinvertebrate community dominated by scrapers. In contrast, total inorganic nitrogen was positively related to the diversity index ( $\mathrm{N}$ range, $0.27-4.24 \mathrm{mgl}^{-1}$ ).

High-order sites (7th order) differed significantly from 4th- to 6th-order sites relative to total biomass (F5) and abundance of filterers (F7) (see Table 6). Increased longitudinal transport of POM generally results from an increase of upstream organic matter input and/or increased instream production. Based on our statistical analyses, a longitudinal trend was found for secondary production, but not for primary production. However, abundance of herbivores
(F3) was positively correlated with periphyton cover, DO, and main substrate diameter and negatively with annual discharge (see Table 6). Thus, results indicated that these metrics, based on abundance of shredder-herbivores and scrapers, are sensitive enough to detect changes in primary production (Merritt et al. 1999; Rezanka and Hershey 2003).

Calcium concentration was positively related to diversity (F1, F2), decomposition (F6), and the ratio of CPOM to FPOM (F11). Limestone is the dominant underlying bedrock in several bioregions in Austria (Wimmer et al. 2000). Geology is a principal factor that explains the variation of ecosystem attributes across stream orders. It is, therefore, important to take regional characteristics into account when a functional assessment is applied to rivers.

Taxa richness (F1) was positively correlated with F3 and F5 (primary and secondary production; see Table 7). Thus, high in-stream productivity seems to be fundamental for maintaining species richness, at least in medium-size rivers. Metrics F3-F6 (material cycling) were in general positively correlated to F7 (longitudinal transport), implying a close relationship between in-stream production and energy transport. Surprisingly, F3 (primary production) was negatively correlated to the ratio of herbivores to detritivores (F4). Considering the positive response of F3 (primary production) to periphyton cover (Table 6), correlation analysis indicated that heterotrophic functional groups (detritivores) increase at a higher rate in abundance than autotrophic groups (herbivores) with increasing periphyton cover. Detritivores might prefer periphyton cover as a habitat, although it is not their primary food source.

Metrics for primary production (F3), secondary production (F5), decomposition (F6), and longitudinal transport (F7) were positively correlated with pollutants such as chlorine and organic halogen compounds, which represent direct anthropogenic (and partly toxic) impacts from agricultural and urban areas (Newman et al. 1987; Fukushima and Kanada 1999). This result implies that functional indicators are affected by toxic substances. For example, organic halogen compounds often result in a dominance of a few tolerant Chironomidae and Oligochaeta taxa (Barbour et al. 2001). As shown in our results, toxic substances may increase some metrics, for example, primary and secondary production, without enhancing ecosystem attributes. Thus, functional assessments should be carefully applied by setting clear targets of stressors because each macroinvertebrate species may exhibit a different response to toxic substances (Hurd et al. 1996; Soucek et al. 2001).

Overall, indicators of ecosystem attributes (metrics F1F13) were closely related to environmental conditions in various ways. Therefore, a function-based approach using FFGs of benthic macroinvertebrates has the potential to be an effective tool for the assessment of the ecological integrity of streams and rivers (Lakly and McArthur 2000). However, future research is required (i) to understand relationships between food availability and macroinvertebrates, as well as their interactions with other biota (e.g., fish), (ii) to determine the sensitivity of individual indicators to vari- 
ous impacts, and (iii) to define reference standards against which ecosystem attributes can be calibrated. In particular, macroinvertebrate abundances cannot simply be converted to biomass, which again is a better determinant of primary and secondary production (Grubaugh et al. 1996). Our results clearly suggest that a function-based approach could complement the more-traditional approaches used for the assessment of river ecosystems (Zelinka and Marvan 1961; Armitage et al. 1983).

Acknowledgments This study was supported by a grant from the Japan Society for the Promotion of Science (JSPS). We acknowledge the Austrian Ministry for Agriculture, Forestry, Environment and Water Management for providing data for the Austrian Monitoring Network. This manuscript was written while Klement Tockner was a sabbatical visitor at the Institute of Ecosystem Studies (IES), Millbrook, NY, USA. Comments by the editor and two anonymous reviewers helped very much to improve the manuscript.

\section{References}

Armitage PD, Moss D, Wright JF, Furse MT (1983) The performance of a new biological water quality score system based on macroinvertebrates over a wide range of unpolluted running-water sites. Water Res 17:333-347

Atmar W, Patterson BD (1993) The measure of order and disorder in the distribution of species in fragmented habitat. Oecologia (Berl) 96:373-382

Aubrecht G, Dick G, Prentice C (1993) Monitoring of ecological change in wetlands of middle Europe. In: Proceedings of an international workshop in Linz, Austria, 26-30 October, pp 137-150

Barbour MT, Gerristen J, Snyder BD, Stribling JB (2001) Rapid bioassessment protocols for use in streams and wadeable rivers: periphyton, benthic macroinvertebrates, and fish. Environmental Protection Agency, Washington, DC

Battin TJ, Kaplan LA, Newbold JD, Hansen CME (2003) Contributions of microbial biofilms to ecosystem processes in stream mesocosms. Nature (Lond) 426:439-442

Bauernfeind E, Moog O (2000) Mayflies (Insecta: Ephemeroptera) and the assessment of ecological integrity: a methodological approach. Hydrobiologia 422/423:71-83

Bayerisches Landesamt für Wasserwirtschaft (1996) Ökologische Typisierung der aquatischen Makrofauna. Bayerisches Landesamt für Wasserwirtschaft, Munich

Boecklen WJ (1997) Nestedness, biogeographic theory, and the design of nature reserves. Oecologia (Berl) 112:123-142

Bundesministerium für Land- und Forstwirtschaft, Umwelt und Wasserwirtschaft (1997) Maps on biological monitoring. In: Wassergüte in Östereich Jahresbericht 1996. Medieninhaber und Herausgeber, Vienna

Bundesministerium für Land- und Forstwirtschaft, Umwelt und Wasserwirtschaft (1998) Ausweisung Flusstypspezifisch Erhaltener Fliessgewässerabschitte in Österreich. Bundesministerium für Landund Fortwirtschaft Wasserwirtschaftskataster, Vienna

Chovanec A, Vogel WR, Winkler G (1996) Aspects of water pollution control of Austrian rivers. Arch Hydrobiol Suppl 113(Large Rivers 10):381-388

Cummins KW, Klug MJ (1979) Feeding ecology of stream invertebrates. Annu Rev Ecol Syst 10:147-172

Cummins KW, Wilzbach MA, Gates DM, Peery JB, Taliaferro WB (1989) Shredders and riparian vegetation. BioScience 39:24-30

Dobson M, Hildrew AG (1992) A test of resource limitation among shredding detritivores in low order streams in southern England. J Anim Ecol 61:69-77

Evans-White MA, Lamberti GA (2005) Grazer species effects on epilithon nutrient composition. Freshw Biol 50:1853-1863

Federal Environment Agency of Austria (2002) Water. In: State of the environment in Austria, Vienna. Federal Environment Agency of Austria, Vienna, pp 43-55
Findlay SEG, Kiviat E, Nieder WC, Blair EA (2002) Functional assessment of a reference wetland set as a tool for science, management and restoration. Aquat Sci 64:107-117

Fukushima S, Kanada S (1999) Effects of chlorine on periphytic algae and macroinvertebrates in a stream receiving treated sewage as maintenance water. Jpn J Limnol 60:569-583

Gayraud S, Statzner B, Bady P, Haybachp A, Schöll F, UsseglioPolatera P, Bacchi M (2003) Invertebrate traits for the biomonitoring of large European rivers: an initial assessment of alternative metrics. Freshw Biol 48:2045-2064

Graça MAS, Cressa C, Gessner MO, Feio MJ, Callies KA, Barrios CC (2001) Food quality, feeding preferences, survival and growth of shredders from temperate and tropical streams. Freshw Biol 46:947957

Grubaugh JW, Wallace JB, Houston ES (1996) Longitudinal changes of macroinvertebrate communities along an Appalachian stream continuum. Can J Fish Aquat Sci 53:896-909

Hawkins CP, Sedell JR (1981) Longitudinal and seasonal changes in functional organization of macroinvertebrate communities in four Oregon streams. Ecology 62:387-397

Hawkins CP, Murphy ML, Anderson NH (1982) Effects of canopy, substrate composition, and gradients on structure of macroinvertebrate communities in Cascade Range streams of Oregon. Ecology 62:387-397

Heltshe JF, Forrester NE (1983) Estimating species richness using the Jackknife procedure. Biometrics 39:1-11

Hieber M, Gessner MO (2002) Contribution of stream detrivores, fungi, and bacteria to leaf breakdown based on biomass estimates. Ecology 83:1026-1038

Hurd MK, Perry SA, Perry WB (1996) Nontarget effects of a test application of diflubenzuron to the forest canopy on stream macroinvertebrates. Environ Toxicol Chem 15:1344-1351

Karr JR, Dudley DR (1981) Ecological perspectives on water quality goals. Environ Manag 5:55-68

Kerans BL, Karr JR (1994) A benthic index of biotic integrity (B-IBI) for rivers of the Tennessee Valley. Ecol Appl 4:768785

Kerr JT, Sugar A, Packer L (2000) Indicator taxa, rapid biodiversity assessment, and nestedness in an endangered ecosystem. Conserv Biol 14:1726-1734

Koller-Kreimel V, Tomek H (1999) Gewässerschutzbericht 1999. Bundesministerium für Land- und Forstwirtschaft, Vienna

Krebs CJ (1999) Species diversity measures. In: Ecological methodology. Addison Wesley Longman, Menlo Park, pp 410-454

Lakly MB, McArthur JV (2000) Macroinvertebrate recovery of a postthermal stream: habitat structure and biotic function. Ecol Eng 15:S87-S100

Lawson DL, Klug MJ, Merritt RW (1984) The influence of physical, chemical, and microbiological characteristics of decomposing leaves on the growth of the detritivore Tipila abdominalis (Diptera: Tipilidae). Can J Zool 62:2339-2343

Lorenz A, Hering D, Feld CK, Rolauffs P (2004) A new method for assessing the impact of hydromorphological degradation on the macroinvertebrate fauna of five German stream types. Hydrobiologia 516:107-127

Malmqvist B, Rundle S (2002) Threats to the running water ecosystems of the world Environ Conserv 29:134-153

Merritt RW, Higgins MJ, Cummins KW, Vandeneeden B (1999) The Kissimmee River-Riparian Marsh Ecosystem, Florida. Seasonal differences in invertebrate functional feeding group relationship. In: Batzer DP, Rader R, Wissinger SA (eds) Invertebrates in freshwater wetlands of North America: ecology and management. Wiley, New York, pp 55-79

Meyer JL, McDowell WH, Bott TL, Elwood JW, Ishizaki C, Melack JM, Peckarsky BL, Peterson BJ, Rublee PA (1988) Elemental dynamics in streams. J North Am Benthol Soc 7:410-432

Minshall GW, Brock JT, Lapoint TW (1982) Characterization and dynamics of benthic organic matter and invertebrate functional feeding group relationships in the Upper Salmon River, Idaho (USA). Int Rev Gesamten Hydrobiol 67:793-820

Moog O (ed) (1995) Fauna Aquatica Austriaca. Bundesministerium für Land- und Forstwirtschaft, Vienna

Moog O, Nesemann H, Ofenböck T (2001a) Österreichs Anteil an denösterreichischen Ökoregionen gemäß EU-Wasserrahmenrichtlinie - eine deduktive Analyse landschaftsprägender 
Milieufaktoren. Österr Wasser- und Abfallwirtschaft 52:204209

Moog O, Schmidt-Kloiber A, Ofenböck T, Gerritsen J (2001b) Aquatische Ökoregionen und Bioregionen Österreichs - eine Gliederung nach geoökologischen Milieufaktoren und Makrozoobenthos-Zönosen. Bundesministerium für Land- und Forstwirtschaft, Umwelt und Wasserwirtschaft,Vienna. www.lebensministerium.at/Wasser/Wasserrahmenrichtlinie [www document]

Muhar S, Schwarz M, Schmutz S, Jungwirth M (2000) Identification of rivers with high and good habitat quality: methodological approach and applications in Austria. Hydrobiologia 422/423:343-358

Newbold JD, O’Neill RV, Elwood JW, Van Winkle W (1982) Nutrient spiralling in streams: implications for nutrient limitation and invertebrate activity. Am Nat 120:628-652

Newman RM, Perry JA, Tam E, Crawford R (1987) Effects of chronic chlorine exposure on litter processing in outdoor experimental streams. Freshw Biol 18:415-428

Ofenböck T, Moog O, Car M (2002) Do the Austrian blackfly fauna (Diptera: Simuliidae) support the typological approach of the EU water framework directive? Limnologica 32:255-272

Parker CR, Voshell JR (1983) Production of filter-feeding Trichoptera in an impounded and free flowing river. Can J Zool 61:70-87

Patterson BD, Atmar W (1986) Nested subsets and the structure of insular mammalian faunas and archipelagoes. Biol J Linn Soc 28:6582

Rawer-Jost C, Böhmer J, Blank J, Rahmann H (2000) Macroinvertebrate functional feeding group methods in ecological assessment. Hydrobiologia 422/423:225-232

Resh VH (1994) Variability, accuracy and taxonomic cost of rapid assessment approaches in benthic macroinvertebrate biomonitoring. Boll Zool 61:375-383

Rezanka KM, Hershey AE (2003) Examining primary producerconsumer interactions in a Lake Superior tributary using ${ }^{15} \mathrm{~N}$-tracer, grazer-reduction, and nutrient-bioassay experiments. J North Am Benthol Soc 22:371-387

Rice WR (1989) Analyzing tables of statistical tests. Evolution 43:223225

Richardson JS (1993) Limits to productivity in streams: evidence from studies of macroinvertebrates. Can Spec Publ Fish Aquat Sci 118:915
Ricklefs RE (1990) Regulation of community structure. In: Ricklefs RE (ed) Ecology. Freeman, New York, pp 748-775

Sorenson T (1948) A method of establishing groups of equal amplitude in plant sociology based on similarity of species content. K Dan Vidensk Selsk Biol Skr 5:1-34

Soucek DJ, Schmidt TS, Cherry DS (2001) In situ studies with Asian clams (Corbicula fluminea) detect acid mine drainage and nutrient inputs in low-order streams. Can J Fish Aquat Sci 58:602608

Vannote RL, Minshall GW, Cummins KW, Sedell JR, Cushing CE (1980) The river continuum concept. Can J Fish Aquat Sci 37:130137

Wallace JB, Anderson NH (1996) Habitat, life history, and behavioural adaptations of aquatic insects. In: Merritt RW, Cummins KW (eds) An introduction to the aquatic insects of North America. Kendall/ Hunt, Dubuque, pp 41-73

Wallace JB, Webster JR (1996) The role of macroinvertebrates in stream ecosystem function. Annu Rev Entomol 41:115-139

Wallace JB, Webster JR, Woodall WR (1977) The role of filterfeedings in flowing waters. Arch Hydrobiol 79:506-532

Ward JV, Tockner K (2001) Biodiversity: towards a unifying theme for river ecology. Freshw Biol 46:807-819

Wimmer R, Moog O (1994) Katalog der Ordnungszahlen österreichischer Fließgewässer. Monographien Bd. 51. Umweltbundesamt, Vienna

Wimmer RA, Chovanec A, Moog O, Fink MH, Gruber D (2000) Abiotic stream classification as a basis for a surveillance monitoring network in Austria in aAccordance with the EU Water Framework Directive. Acta Hydrochim Hydrobiol 28:177-184

World Resources Institute (2001) Part 2: Taking stock of ecosystem. In: World Resources Institute (ed) World Resources 2000-2001. Elsevier, Washington, DC, pp 43-145

Wotton RS (1987) Lake outlet black flies - the dynamics of filter feeders at very high population densities. Holarct Ecol 10:65-72

Wright JF (2000) An introduction to RIVPACS. In: Assessing the biological quality of fresh waters RIVPACS and other techniques. Freshwater Biological Association, Ambleside, pp 1-24

Wright DH, Reeves JH (1992) On the meaning and measurement of nestedness of species assemblages. Oecologia (Berl) 92:416-428

Zelinka M, Marvan P (1961) Zur Präzisierung der biologische Klassifikation der Reinheit fliessender Gewässer. Arch Hydrobiol 57:389-407 